\title{
Development of the Numerical Model for Complex Transport of Radionuclide and Colloid in the Single Fractured Rock
}

\section{단일 균열암반에서 핵종/콜로이드 복합이동에 대한 수치모델 개발}

\author{
Sanghwa Lee ${ }^{1}$, Jung-woo Kim ${ }^{2 *}$ and Jongtae Jeong ${ }^{2}$ \\ ${ }^{1}$ Kyung Hee University, Dukyoungdaero 1732, Giheung-gu, Yongin, Gyeonggi-do, Korea \\ ${ }^{2}$ Korea Atomic Energy Research Institute, Daedeokdaero 989-111, Yuseong-gu, Daejeon, Korea \\ 이상화 ${ }^{1}$, 김정우 $2^{*}$, 정종태 ${ }^{2}$ \\ 1 경희대학교, 경기도 용인시 기흥구 덕영대로 1732 \\ 2 한국원자력연구원, 대전시 유성구 대덕대로 989 번길 111
}

(Received July 19, 2012 / Revised August 08, 2012 / Approved October 23, 2012)

In this study, numerical model for transport of radionuclide and colloid was developed. In order to solve reaction-migration governing equation for colloid and radionuclide, Strang-splitting Sequential Non-Iterative (SNI), which is one of Operator Splitting Method, was used for numerical method and this was coded by MATLAB. From the verification by comparing the simulation results with analytical solution considering only solute transport and rock diffusion, the Pearson's correlation coefficient was greater than 0.99 which demonstrates the accuracy of the model.

Key words: Transport, Colloid, Radionuclide, Numerical model, Advection-dispersion

본 연구에서는 콜로이드와 핵종의 복합이동에 관한 수치모델을 개발하였다. 콜로이드와 핵종의 반응-이동 지배방정식을 풀 기 위하여 Operator Splitting Method 중 Strang의 분리 SNI 방식을 수치해석 방법으로 채택하였고 이는 MATLAB을 이용하여 코드화 되었다. 개발된 수치모델은 용질의 이동 및 분산만을 고려한 해석해를 통한 검증과정에서 피어슨 상관계수의 제곱값 $\left(r^{2}\right)$ 이 0.99 이상으로 나타나 모델의 정확성이 입증되었다.

중심단어: 이동, 콜로이드, 방사성핵종, 수치모델, 이류-분산

*Corresponding Author .E-mail: jw_kim@kaeri.re.kr, Tel: +82.42.868.2547

\section{1. 서 론}

중·저준위 방사성폐기물과는 달리 고준위 방사성폐기물 은 인간 및 생태계에 매우 위협적인 양의 방사능을 갖는다. 이와 같은 고준위 폐기물을 생태계와 격리시키기 위한 심 지층처분장에는 다중방벽의 개념을 도입하여 폐기물로부
터 나오는 유독물질의 이동을 늦추거나 차단한다. 특히 천 연 방벽인 모암은 낮은 수리전도도와 높은 수착 능력으로 핵종의 이동을 지연시키는 역할을 한다. 하지만 암반에는 수많은 균열이 있는데 이는 지하수의 이동통로의 역할을 함과 동시에 방사성 핵종을 생태계로 이어주는 통로의 역 할을 하게 된다. 균열을 따라 이동하는 방사성 핵종들은 암 반 매질, 균열 충진 물질, 다양한 종류의 콜로이드, 유기물, 
미생물 등과 상호작용을 함으로써 그 이동성이 빨라지거나 늦춰질 수 있다. 특히 콜로이드의 구성종류 중 벤토나이트 는 많은 핵종들에 대해 뛰어난 수착능을 가지고 있음을 고 려할 때 점토입자들은 핵종 이동에 영향을 미칠 수 있다[1]. 콜로이드는 지하수가 흐르는 어느 곳에나 존재하고 지하수 와 폐기물 처분장의 완충재와의 반응으로 생성될 수 있으 며 이들은 방사성 핵종의 이동을 촉진시킨다[2]. 실례로 미 국 Nevada 주의 실험 장소에서 $1.3 \mathrm{~km}$ 떨어진 곳에서 플루 토늄이 발견된 바 있다[3]. 이는 지하수에서 용질 이동시 핵 종의 수착반응을 고려한다면 일어나기 어려운 일이다. 하 지만 콜로이드는 지하수 흐름보다 빠르게 이동하고 또 어 떤 핵종은 콜로이드에 흡착되어 이동할 수 있기 때문에 가 능한 일이다. 즉, 위에서 발견된 플루토늄은 콜로이드가 플 루토늄 이동을 촉진시켰기 때문에 먼 거리까지 도달한 것 이다. 이와 같이 콜로이드는 핵종의 이동을 촉진시키기 때 문에 고준위 폐기물 처분의 안전성을 확보하기 위하여 이 와 관련된 실험을 진행하여 핵종 이동에 대한 정보를 수집 할 필요가 있다.

고준위 폐기물은 처분장의 폐쇄 후에도 장기간 안전성이 보장되어야 하는데 실험만으로는 장기간 안전성 보장에 어 려움이 따르기 때문에 이를 보완해 줄 수치모델이 동반되어 야 한다. 이미 해외에서는 스웨덴의 Äspö와 스위스의 GTS 실험장 같이 핵종 이동 실험과 수치모델 개발이 수행되고 있 는 실정이다. Äspö의 연구 프로젝트 중 삼차원 추적자 이동 실험은 현장에서 핵종이동 실험을 수행하는 팀, 실험을 해석 하고 예측하기위한 이동모델을 개발하는 팀으로 분반해서 연구하고 있고 이미 1, 2단계 연구가 진행되어 2007년에 최 종보고서가 발간되었다. 스위스 GTS에서도 콜로이드 형성 및 이동 실험을 통하여 핵종이동에 대한 성능평가에 사용될 컴퓨터 코드의 검증 및 개선을 위해 현재 2단계(2008 2013) 연구를 진행 중에 있다. 우리나라에서도 지난 2006년 11월 한국원자력연구원 부지 내에 고준위폐기물 처분을 위한 소 규모 지하연구시설인 KURT(KAERI Underground Research Tunnel)이 건설 되어 활발한 연구가 진행 중에 있다[4]. 하지 만 KURT는 약 $100 \mathrm{~m}$ 수준으로 심도가 낮고 방사성 물질을 이용할 수 없다는 단점이 있다. 또 실제 처분장 수준의 연구 시설을 국내에 건설하기에는 부지와 예산확보, 장기간의 건 설기간 등의 문제점이 있기 때문에 국제공동연구 참여와 수 치모델 개발의 필요성이 있다.

따라서 본 연구에서는 단일 균열 암반에서 콜로이드가 핵 종이동에 미치는 영향을 규명하기 위하여 수치모델을 제 시하고 가상의 주어진 조건에서 모델의 실행 예를 기술하 였다.

\section{2. 연구 방법}

\section{1 개념 모델}

본 연구에서는, 단일 균열암반에서 핵종과 콜로이드 의 복합반응을 고려한 이동현상을 재연하기 위해서 여러 가지 현상들을 모델 개발에서 고려하였고, 이는 <Fig. 1>에서 도식화되었고 <Fig. 1>에서 사용된 축 약어는 <Table $1>$ 에 정리하였다. 이러한 현상들은 크 게 균열 공간, 균열 표면, 암반 공극, 그리고 암반 매질 에서 일어나는 현상들로 분류 할 수 있다. 고준위 폐기 물 처분장으로부터 유출된 핵종은 완충재로부터 유출 되는 콜로이드와 함께 암반의 균열을 따라 이동하게 된다. 핵종은 균열을 따라 단독 혹은 콜로이드에 흡착 되어 이동할 수 있고 균열 표면에 흡착 혹은 균열 표 면에 흡착된 콜로이드에 흡착될 수 있다. 핵종은 암반 공극으로의 확산이 될 수 있으나 콜로이드는 일반적 인 암반 매질의 공극의 크기보다 그 크기 때문에 공극 으로의 확산을 고려하지 않는다[5]. 방사성 핵종은 시 간에 따라서 그 방사능이 줄어들기 때문에 이도 같이 고려해 주었다.

\section{2 수학 모델}

\subsection{1 이동 지배방정식}

단일 균열 암반에서의 이동 지배방정식은 크게 콜로이드의 이동 지배방정식과 핵종(용질) 이동 지배방정식, 두 가지로

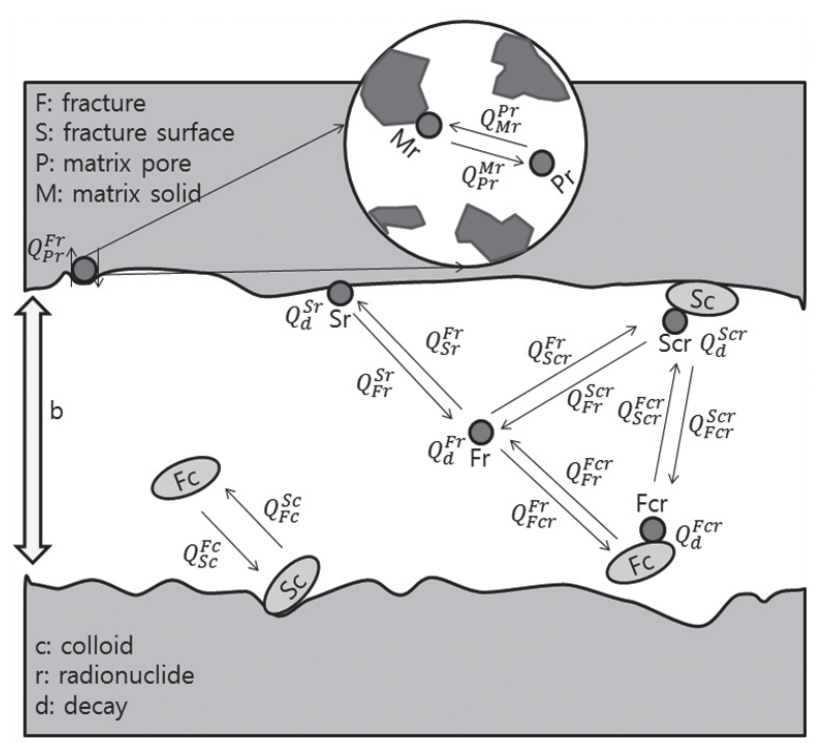

Fig. 1. Conceptual model for colloid-radionuclide interaction in fractured rock. 
Table 1. Explanations of Abbreviations for the reaction terms used in $<$ Fig. 1>

\begin{tabular}{|c|c|}
\hline Abbreviations & Value \\
\hline$Q_{P r}^{F r}$ & The rate of radionuclide diffusion from fracture into rock matrix. \\
\hline$Q_{S c}^{F c}$ & $\begin{array}{l}\text { The sorption rate of colloid from fracture water to fracture sur- } \\
\text { face. }\end{array}$ \\
\hline$Q_{F c}^{S c}$ & $\begin{array}{l}\text { The desorption rate of colloid from fracture surface to fracture } \\
\text { water. }\end{array}$ \\
\hline$Q_{d}^{S r}$ & The decay rate of radionuclide adsorbed onto fracture surface. \\
\hline$Q_{S r}^{F r}$ & $\begin{array}{l}\text { The sorption rate of radionuclide from fracture water to fracture } \\
\text { surface. }\end{array}$ \\
\hline$Q_{F r}^{S r}$ & $\begin{array}{l}\text { The desorption rate of radionuclide from fracture surface to frac- } \\
\text { ture water. }\end{array}$ \\
\hline$Q_{d}^{F r}$ & The decay rate of radionuclide located in fracture water. \\
\hline$Q_{S c r}^{F r}$ & $\begin{array}{l}\text { The sorption rate of radionuclide from fracture surface to surface of } \\
\text { the colloid, located on fracture surface. }\end{array}$ \\
\hline$Q_{F r}^{S c r}$ & $\begin{array}{l}\text { The desorption rate of radionuclide from surface of the colloid, } \\
\text { located on fracture surface, to fracture water. }\end{array}$ \\
\hline$Q_{F c r}^{F r}$ & $\begin{array}{l}\text { The sorption rate of radionuclide from fracture water to surface of } \\
\text { the colloid, located in fracture water. }\end{array}$ \\
\hline$Q_{F r}^{F c r}$ & $\begin{array}{l}\text { The desorption rate of radionuclide from surface of the colloid, } \\
\text { located in fracture water, to fracture water. }\end{array}$ \\
\hline$Q_{d}^{S c r}$ & $\begin{array}{l}\text { The decay rate of radionuclide adsorbed on the colloid located in } \\
\text { fracture water. }\end{array}$ \\
\hline$Q_{S c r}^{F c r}$ & $\begin{array}{l}\text { The sorption rate of radionuclide adsorbed on the surface of the } \\
\text { colloid, located in fracture water, to the surface of the colloid, lo- } \\
\text { cated on fracture surface. }\end{array}$ \\
\hline$Q_{F c r}^{S c r}$ & $\begin{array}{l}\text { The sorption rate of radionuclide adsorbed on the surface of the } \\
\text { colloid, located on fracture surface, to the surface of the colloid, } \\
\text { located in fracture water. }\end{array}$ \\
\hline$Q_{d}^{F c r}$ & $\begin{array}{l}\text { The decay rate of radionuclide adsorbed on the surface of the col- } \\
\text { loid, located in fracture water. }\end{array}$ \\
\hline$Q_{M r}^{P_{r}}$ & The sorption rate of radionuclide from pore to rock matrix. \\
\hline$Q_{P r}^{M / r}$ & The desorption rate of radionuclide from rock matrix to pore. \\
\hline
\end{tabular}

나누었다. 이들 지배 방정식은 단일 균열에서 1차원 이류-분 산 방정식(advection - dispersion equation)에 콜로이드와 핵종의 동역학적(kinetic) 반응들이 더하여진다.

\subsubsection{1 콜로이드 이동 지배방정식}

1 차원 이류-분산 방정식에 콜로이드의 동역학적 반응들을 더한 콜로이드의 이동 지배방정식은 다음과 같다.

$$
\frac{\partial F_{c}}{\partial t}=-v_{c} \frac{\partial F_{c}}{\partial z}+D \frac{\partial^{2} F_{c}}{\partial z^{2}}-Q_{S c}^{F c}+Q_{F c}^{S c}\left(v_{c}=1.1 v\right)
$$

여기서, $F_{c}$ 는 암반 균열에서 콜로이드의 농도 $\left(\mathrm{g} / \mathrm{m}^{3}\right), v$ 는 암반 균열에서 지하수 유속 $(\mathrm{m} / \mathrm{s}), D_{C}$ 는 암반 균열에서 콜로 이드의 수리분산 계수 $\left(\mathrm{m}^{2} / \mathrm{s}\right), t$ 는 시간 $(s)$, 그리고 $z$ 는 암반
균열 방향으로의 거리 $(\mathrm{m})$ 이다. 여기서 $v_{C}$ 는 콜로이드의 유속으로 지하수보다 평균적으로 약 1.1 배 빠르다고 가정하 였다. 암반 균열에서 콜로이드의 수리분산 계수 $\left(D_{C}\right)$ 는 유속 에 의한 이산(advection)으로 다음과 같이 정의된다.

$$
D_{c}=\alpha_{c} v_{c}
$$

여기서, $\alpha_{c}$ 는 암반 균열에서 콜로이드의 분산계수(dispersivity) (m) 이다. 또한, 암반 균열 표면에 흡착된 콜로이 드의 농도 변화는 이류 및 분산에 영향을 받지 않는다고 가 정하면 다음 식과 같다.

$\frac{2}{b} \frac{\partial S_{c}}{\partial t}=Q_{S c}^{F c}-Q_{F c}^{S c}$

여기서, $S_{C}$ 는 암반 균열 표면에 흡착된 콜로이드의 농도 $\left(\mathrm{g} / \mathrm{m}^{3}\right)$, 그리고 $b$ 는 암반 균열 간극의 거리 $(\mathrm{m})$ 이다.

식(1)과 (2)에서 사용된 동역학적 반응들의 속도를 나타낸 $Q\left(\mathrm{~g} / \mathrm{m}^{3} / \mathrm{s}\right)$ 항들의 정의는 다음과 같다.

$Q_{S c}^{F c}$ 는 암반 균열에 존재하는 콜로이드가 암반 균열 표면 으로 흡착하는 속도, $Q_{F c}^{S c}$ 는 암반 균열 표면에 흡착된 콜로 이드가 암반 균열로 탈착하는 속도이다. 이와 같은 동역학적 반응들은 〈Fig. 1〉에 형상화 되어있다.

\subsubsection{2 핵종 이동 지배방정식}

콜로이드는 입자가 크기 때문에 암반 균열부에서만 이동 을 하지만 지하수에 용존하는 핵종은 암반 공극으로 확산을 한다. 게다가 핵종의 방사능 붕괴까지 고려해야하므로 핵종 의 이동 지배방정식은 콜로이드의 이동 지배방정식보다 약 간 더 복잡하다. 암반 균열에서의 핵종 농도에 대한 방정식 은 다음과 같다.

$$
\begin{aligned}
\frac{\partial F_{r}}{\partial t} & =-v \frac{\partial F_{r}}{\partial z}+D_{r} \frac{\partial^{2} F_{r}}{\partial z^{2}} \\
& -Q_{S r}^{F r}+Q_{F r}^{S r}-Q_{F c r}^{F r}+Q_{F r}^{F c r}-Q_{S c r}^{F r}+Q_{F r}^{S c r}-Q_{d}^{F r}
\end{aligned}
$$

여기서, $F_{r}$ 는 암반 균열에서 핵종의 농도 $\left(\mathrm{g} / \mathrm{m}^{3}\right)$, 그리고 $D_{r}$ 는 암반 균열에서 핵종의 수리분산 계수 $\left(\mathrm{m}^{2} / \mathrm{s}\right)$ 이다. 핵 종의 수리분산 계수 $\left(D_{r}\right)$ 는 콜로이드의 수리분산 계수와 비 슷하지만 분자의 확산 항이 더해지면서 다음과 같이 정의 된다 [6].

$$
D_{r}=\alpha_{r} \vartheta+D_{r}^{*}
$$

여기서, $\alpha_{r}$ 는 암반 균열에서 핵종의 분산계수 $(\mathrm{m})$, 그리고 $D_{r}^{*}$ 


\section{Sanghwa Lee. et al : Development of the Numerical Model for Complex Transport of Radionuclide and Colloid in the}

Single Fractured Rock

는 물과 같은 자유공간에서 핵종의 분자확산 계수 $\left(\mathrm{m}^{2} / \mathrm{s}\right)$ 이다.

암반 균열 표면에 흡착된 핵종의 농도 변화가 이류와 분산 에 영향을 받지 않는다고 가정하면 다음 식과 같다.

$$
\frac{2}{b} \frac{\partial S_{r}}{\partial t}=Q_{S r}^{F r}-Q_{F r}^{S r}-Q_{d}^{S r}
$$

여기서, $S_{r}$ 는 단위면적당 암반 균열 표면에 흡착된 핵종의 농도 $\left(\mathrm{g} / \mathrm{m}^{2}\right)$ 이다.

암반 균열에서 이동하는 콜로이드에 흡착된 핵종은 콜로 이드의 이동 특성에 따라 이동하게 되므로 식으로 정리하면 식(5)와 같다.

$$
\begin{aligned}
\frac{\partial \sigma_{F c r} F_{c}}{\partial t}= & -v \frac{\partial \sigma_{F c r} F_{c}}{\partial z}+D_{c} \frac{\partial^{2} \sigma_{F c r} F_{c}}{\partial z^{2}} \\
& +Q_{F c r}^{F r}-Q_{F r}^{F c r}-Q_{S c r}^{F c r}+Q_{F c r}^{S c r}-Q_{d}^{F c r}
\end{aligned}
$$

여기서, $\sigma_{F c r}$ 는 암반 균열에 존재하는 콜로이드 표면에 흡 착된 핵종의 질량비이다.

다음으로 암반 균열 표면에 흡착된 콜로이드에 흡착되는 핵종에 대한 식은 이류와 분산에 영향을 받지 않는다고 가 정하면 다음과 같다.

$$
\frac{2}{b} \frac{\partial \sigma_{S c r} S_{r}}{\partial t}=Q_{S c r}^{F r}-Q_{F r}^{S c r}+Q_{S c r}^{F c r}-Q_{F c r}^{S c r}-Q_{d}^{S c r}
$$

여기서, $\sigma_{S c r}$ 는 암반 균열 표면에 흡착된 콜로이드에 흡착 된 핵종의 질량비이다.

암반 공극에서의 핵종 농도 변화는 화강암의 공극의 크기 가 수 $\mathrm{nm}$ 이하임을 고려해서 지하수의 흐름은 고려하지 않 고 오직 확산에 의해서만 핵종이 이동한다고 가정하였다. 핵 종의 암반 공극으로의 확산은 식(7)과 같이 균열방향의 직각 방향으로 1 차원적으로 나타내었다.

$$
\frac{\partial P_{r}}{\partial t}=D_{M r} \frac{\partial^{2} P_{r}}{\partial x^{2}}-Q_{M r}^{\mathrm{Pr}}+Q_{\mathrm{Pr}}^{M r}-Q_{d}^{\mathrm{Pr}}
$$

여기서 $P_{r}$ 는 암반 공극에서 핵종의 농도 $\left(\mathrm{g} / \mathrm{m}^{3}\right), D_{M r}$ 는 암반 공극에서 핵종의 수리확산 계수 $\left(\mathrm{m}^{2} / \mathrm{s}\right)$, 그리고 $x$ 는 암반 균열과 수직방향으로의 거리 $(\mathrm{m})$ 이다. 암반 공극에서 핵종의 수리확산 계수 $\left(D_{M r}\right)$ 는 분자확산만을 고려하여 다음 과 같이 정의된다[6].

$$
D_{M r}={ }_{\tau} D_{c}^{*}
$$

여기서, $\tau$ 는 암반 공극의 굴곡비(totuosity)로 경로의 직 선거리와 실제 유체가 이동한 거리의 비의 제곱이다.

마지막으로, 암반 매질 표면에서의 핵종 농도 변화는 다음 과 같다.

$$
\frac{1}{\theta} \frac{\partial M_{r}}{\partial t}=Q_{M r}^{P r}-Q_{\mathrm{Pr}}^{M r}-Q_{d}^{M r}
$$

여기서, $M_{r}$ 는 암반 매질 표면에 흡착된 핵종의 농도 $\left(\mathrm{g} / \mathrm{m}^{3}\right)$, 그리고 $\theta$ 는 암반의 공극률이다.

핵종의 이동 지배방정식에서 사용된 동역학적 반응들은 $Q$ 로 나타내었고, 이는〈Fig. 1〉에 형상화 되어있다.

\subsection{2 동역학적 반응}

콜로이드와 핵종의 이동 지배방정식에서의 동역학적 반응 들은 모두 1차 반응속도(1st-order kinetics)로 가정하였다.

\subsubsection{1 암반 균열에서 암반 공극으로의 핵종 확산}

암반 균열에서 암반 공극으로의 핵종 이동은 농도차로 인 한 확산(diffusion)에 의해서 이루어진다. 따라서 이러한 이 동을 Fick's first law에 의해서 나타내었다.

$$
Q_{\mathrm{Pr}}^{F r}=-\frac{2 \theta D_{M r}}{b} \frac{P_{r}(z, 0)-F_{r}(z)}{\Delta x}
$$

\subsection{2 콜로이드의 흡착과 탈착}

암반 균열에서 균열 표면으로 콜로이드의 흡착과 탈착의 속도는 암반 균열에 존재하는 콜로이드의 농도에 1 차원적으 로 비례한다고 가정하였다. 식(10)과 식(11)은 각각 콜로이 드의 흡착과 탈착 속도에 관한 식이다.

$$
\begin{aligned}
Q_{S c}^{F c} & =k_{S c}^{F c} F_{c} \\
Q_{F c}^{S c} & =k_{F c}^{S c} \frac{2 S_{c}}{b}
\end{aligned}
$$

여기서, $k_{S c}^{F c}$ 는 콜로이드가 암반 균열에서 암반 균열 표면 으로 흡착하는 속도 계수 $(1 / s)$, 그리고 $k_{F c}^{S c}$ 는 콜로이드가 암반 균열 표면에서 암반 균열로 탈착하는 속도 계수 $(1 / s)$ 이다.

콜로이드의 흡착과 탈착은 콜로이드 표면에 흡착된 핵종 의 이동에 영향을 미치게 된다. 이러한 흡착(식(12))과 탈착 (식(13))에 대하여 아래와 같이 나타내었다.

$$
Q_{S c r}^{F c r}=\sigma_{F c r} Q_{S c}^{F c}
$$




$$
Q_{F c r}^{S c r}=\sigma_{S c r} Q_{F c}^{S c}
$$

\subsubsection{3 핵종의 흡착과 탈착}

암반 균열에서 표면으로 핵종의 흡착과 탈착의 속도는 암 반 균열에 존재하는 핵종의 농도와 암반 표면에 존재하는 핵종의 농도에 각각 1차원적으로 비례한다고 가정하였다. 식(14)는 핵종의 흡착, 식(15)는 핵종의 탈착 속도를 나타 낸다.

$$
\begin{gathered}
Q_{S r}^{F r}=k_{S r}^{F r} F_{r} \\
Q_{F r}^{S r}=k_{F r}^{S r} \frac{2 S_{r}}{b}
\end{gathered}
$$

여기서, $k_{S r}^{F r}$ 는 핵종이 암반 균열에서 암반 균열 표면으로 흡착하는 속도 계수 $(1 / s)$, 그리고 $k_{F r}^{S r}$ 는 핵종이 암반 균열 표면에서 암반 균열로 탈착하는 속도 계수 $(1 / s)$ 이다.

암반 균열에서 핵종이 콜로이드로 흡착하는 정도는 핵종 과 콜로이드의 농도 모두를 고려해 주어야 한다. 따라서 암 반 균열에서 핵종이 콜로이드에 흡착하는 속도를 암반 균열 에 존재하는 콜로이드에 흡착하는 속도(식(16))와 암반 균열 표면에 흡착된 콜로이드에 흡착하는 속도(식(17))에 대해서 아래와 같이 정의하였다.

$$
\begin{aligned}
& Q_{F c r}^{F r}=k_{F c r}^{F r} F_{r} \\
& Q_{S c r}^{F r}=k_{S c r}^{F r} F_{r}
\end{aligned}
$$

여기서, $k_{F c r}^{F r}$ 는 핵종이 암반 균열에서 암반 균열에 존재 하는 콜로이드 표면으로 흡착하는 속도 계수 $(1 / s), k_{S c r}^{F r}$ 는 핵종이 암반 균열에서 암반 균열 표면에 흡착된 콜로이드 표 면으로 흡착하는 속도 계수 $(1 / s)$ 이다.

암반 균열에 존재하는 콜로이드로부터 핵종의 탈착 속도 는 흡착된 핵종의 농도에 1 차원 적으로 비례한다고 가정하 여 암반 균열에 존재하는 콜로이드(식(18))와 균열 표면에 흡착된 콜로이드(식(19))에 대해서 각각 다음과 같이 정의 하였다.

$$
\begin{aligned}
& Q_{F r}^{F c r}=k_{F r}^{F c r} \sigma_{F c r} F_{c} \\
& Q_{F r}^{S c r}=k_{F r}^{S c r} \sigma_{S c r} \frac{2 S_{c}}{b}
\end{aligned}
$$

여기서, $k_{F r}^{F c r}$ 는 핵종이 암반 균열에 존재하는 콜로이드 표 면에서 암반 균열로 탈착하는 속도 계수 (1/s), 그리고 $k_{F r}^{S c r}$ 는 핵종이 암반 균열 표면에 흡착된 콜로이드 표면에서 암반 균열로 탈착하는 속도 계수 $(1 / \mathrm{s})$ 이다.

암반 공극에서 핵종 흡착과 탈착 속도는 암반 공극에 존재 하는 핵종의 농도와 암반 매질에 흡착된 핵종의 농도에 1차 원적으로 비례한다고 가정하였다. 흡착(식(20))과 탈착 (식 (21)) 속도는 아래와 같다.

$$
\begin{aligned}
& Q_{M r}^{\mathrm{Pr}}=k_{M r}^{\mathrm{Pr}} P_{r} \\
& Q_{\mathrm{Pr}}^{M r}=k_{\mathrm{Pr}}^{M r} \frac{M_{r}}{\theta}
\end{aligned}
$$

여기서, $k_{M_{r}}^{\mathrm{Pr}}$ 는 핵종이 암반 공극에서 암반 매질 표면으 로 흡착하는 속도 계수 $(1 / \mathrm{s})$, 그리고 $k_{\mathrm{Pr}}^{M r}$ 는 핵종이 암반 매질 표면에서 암반 공극으로 탈착하는 속도 계수 $(1 / \mathrm{s})$ 이다.

\subsubsection{4 핵종의 감쇠}

방사성 핵종은 반감기를 가지므로, 핵종의 감쇠를 다음과 같이 암반 균열과 암반 공극, 그리고 콜로이드 표면에서 각 각 1 차 반응으로 가정하였다.

$$
\begin{aligned}
& Q_{d}^{F r}=\lambda_{r} F_{r} \\
& Q_{d}^{S r}=\lambda_{r} \frac{2 S_{r}}{b} \\
& Q_{d}^{\mathrm{Pr}}=\lambda_{r} P_{r} \\
& Q_{d}^{M r}=\lambda_{r} \frac{M_{r}}{\theta} \\
& Q_{d}^{F c r}=\lambda_{r} \sigma_{F c r} F_{c} \\
& Q_{d}^{S c r}=\lambda_{r} \frac{2 S_{c}}{b}
\end{aligned}
$$

여기서, $\lambda_{r}$ 는 핵종의 감쇠 계수 $(1 / s)$ 로, 핵종의 반감기 $\left(t_{r}^{1 / 2}\right)$ 를 이용해 다음과 같이 계산된다.

$$
\lambda_{c}=\frac{1 \mathrm{n} 2}{t_{r}^{1 / 2}}
$$




\section{3 수치해석}

앞에서 설명된 이류-분산(advection-dispersion) 방정식과 동역학적(kinetic) 반응식들의 합은 비선형 방정식이기 때문 에 이론적 해석해를 구하는 것이 매우 어렵거나 불가능하다. 따라서 적절한 수치해석 방법을 사용하여 수치해를 구할 수 밖에 없다. 본 연구에서는 이류-분산 방정식과 동역학적 반 응식들을 별개로 계산하는 Operator Splitting Method를 사 용하여 해당 방정식의 수치해를 구하였다.

\subsubsection{Operator Splitting Method(OSM)}

Operator Splitting Method는 콜로이드와 핵종의 동역학적 반응식을 포함한 이류-분산 방정식의 해석해를 구하는데 있 어서 계산 효율을 상당히 향상시켜 준다. 이 방법은 이류-분 산 방정식과 동역학적 반응식을 별개의 계산 방법으로 각각 계산하는 방법이다.

일반적으로 $\mathrm{m}$ 개의 용질에 대한 반응-이동 방정식은 다음 과 같이 주어진다.

$$
\frac{\partial C_{e}}{\partial t}=L\left(C_{e}, z\right)+f_{e}\left(C_{1}, C_{2}, \ldots C_{e}, \ldots, C_{m}\right)
$$

여기서, $C_{e}$ 는 용질 e의 농도, $\mathrm{L}\left(C_{e}, z\right)$ 는 용질 e의 이류-분산 항으로 다른 용질의 영향을 받지 않고, $f_{e}\left(C_{1}, C_{2}, \ldots C_{e}, \ldots\right.$, $C_{m}$ )는 용질 e의 반응항으로 다른 용질의 농도에 영향을 받 는다.

이에 대한 Operator Splitting Method는 계산 순서와 반복 계산 여부에 따라 표준 순차 무반복(Sequential non-iterative; SNI) 방 식, Strang의 분리(Strang-splitting) 순차 무반복(Sequential noniterative; SNI) 방식, 표준 순차 반복(Sequential iterative; SI) 방 식, 그리고 대칭 순차 반복(Symmetric sequential iterative) 방식 으로 나누어진다. 본 연구에서는 모델의 안정성에 문제없이 정 확한 결과를 도출해 낼 수 있는 Strang의 분리 SNI방식을 채택 하여 이동-반응 모델의 수치해를 구하였다[7].

Strang의 분리 SNI 방식은 단위 시간 간격을 반으로 나누 어서 반응식들을 제외한 용질 이류-분산 방정식을 각 용질 $\mathrm{e}$ 에 대해서 다음과 같이 먼저 계산한다.

$$
\begin{aligned}
& \frac{C_{e}^{n+1 / 2,{ }^{*}}-C_{e}^{n}}{\Delta t / 2}= \\
& -v \nabla C_{e}^{n+1 / 2,{ }^{*}}+\nabla\left(D \nabla C_{e}^{n+1 / 2,{ }^{*}}\right)
\end{aligned}
$$

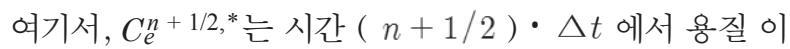

류-분산 방정식에 의해 계산된 용질 e의 농도(임시값)이다.

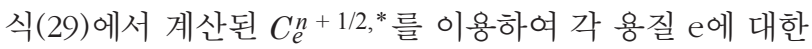
반응식을 순차적으로 계산한다.

$$
\begin{aligned}
& \frac{C_{e}^{n+1,{ }^{* *}}-C_{e}^{n+1 / 2, *}}{\Delta t}= \\
& f_{e}\left(C_{1}^{n+1 / 2, *}, C_{2}^{n+1 / 2, *}, \ldots, C_{e}{ }^{n+1 / 2, *}, \ldots, C_{m}^{n+1 / 2, *}\right)
\end{aligned}
$$

여기서, $C_{e}^{n+1, * *}$ 는 시간 $(n+1) \cdot \Delta t$ 에서 용질 반응 에 의해 계산된 용질 e의 농도(임시값)이다. 식(30)에서 계 산된 $C_{e}^{n+1, * *}$ 를 이용하여 나머지 시간 간격 반에 대한 용 질 이류-분산 방정식을 각 용질 e에 대해서 다음과 같이 다 시 계산한다.

$$
\begin{aligned}
& \frac{C_{e}^{n+1}-C_{e}^{n+1, * *}}{\Delta t / 2}= \\
& -v \nabla C_{e}^{n+1}+\nabla\left(D \nabla C_{e}^{n+1}\right)
\end{aligned}
$$

\subsection{2 콜로이드 및 용질 이류-분산}

\subsubsection{1 암반 균열에서 콜로이드의 이류-분산}

암반 균열에서 콜로이드의 이류-분산 방정식에 대하여 본 연구에서는 경계조건으로 유입구에서는 콜로이드가 고정농 도로 주입된다고 가정하였고 유출구에서는 0 구배 농도 조 건을 사용하였다. 초기조건으로는 최초 암반 균열에 콜로이 드가 없다고 설정하였다. 초기조건과 경계조건을 식으로 표 현하면 아래와 같다.

$$
\begin{gathered}
F_{c}\left(0 \sim t_{1}, 0\right)=0, F_{c}\left(t_{1} \sim t_{2}, 0\right)=F_{c, s r c}, F_{c}\left(t_{2} \sim, 0\right)=0, \\
F_{c}(t, Z)=F_{c}(t, Z-1), \\
F_{c}(0, k)=0(k=1, \ldots, Z)
\end{gathered}
$$

\subsubsection{2 암반 균열에서 용질의 이류-분산}

암반 균열에서 용질 이류-분산 방정식에 대하여 본 연구에 서 사용한 경계조건으로, 유입구에서는 고정농도 조건이, 그리고 유출구에서는 0 구배농도 조건이 설정되었다. 초기 조건으로는, 최초 암반 균열에 용질이 존재하지 않는다고 가정하였다. 이들을 수식으로 표현하면 다음과 같다.

$$
\begin{gathered}
F_{r}(t, 0)=F_{r, s r c}, \\
F_{c}(t, Z)=F_{r}(t, Z-1), \\
F_{r}(0, k)=0(k=1, \ldots, Z)
\end{gathered}
$$

\subsubsection{3 암반 균열에서 콜로이드 표면에 흡착된 용질의 이류- 분산 \\ 암반 균열에서 콜로이드 표면에 흡착된 용질의 이류-분산}


방정식에 대하여 본 모델에서 사용한 경계조건으로, 유입구 에서는 고정농도 조건이, 그리고 유출구에서는 0 구배농도 조건이 설정되었다. 초기조건으로는, 최초 암반 균열에 콜 로이드 표면에 흡착된 용질이 존재하지 않는다고 가정하였 다. 이들을 수식으로 표현하면 다음과 같다.

$$
\begin{gathered}
\sigma_{F c r}(t, 0) \cdot F_{c}(t, 0)=\sigma_{F c r, s r c} \cdot F_{c, s s c}, \\
\sigma_{F c r} \cdot F_{c}(t, Z)=\sigma_{F c r} \cdot F_{c}(t, Z-1), \\
\sigma_{F c r}(0, k)=0(k=1, \ldots, Z)
\end{gathered}
$$

\subsubsection{4 암반 공극에서 용질의 확산}

암반 공극에서 용질 확산 방정식에 대하여 본 연구에서 사 용한 경계조건으로, 유입구에서는 고정농도 조건으로 각 시 간별 암반 균열에서의 용질 농도가, 그리고 유출구에서는 0 구배농도 조건이 설정되었다. 초기조건으로는, 최초 암반 공 극에 용질이 존재하지 않는다고 가정하였다. 이들을 수식으 로 표현하면 다음과 같다.

$$
\begin{gathered}
P_{r}(t, k, 0)=F_{r}(t, k)(k=1, \ldots, Z) \\
P_{r}(t, k, X)=P_{r}(t, k, X-1)(k=1, \ldots, Z) \\
P_{r}(0, k, i)=0(k=1, \ldots, Z)(i=1, \ldots, X)
\end{gathered}
$$

\section{3. 결과 및 논의}

\section{1 모델 실행 영역}

모델 실행 영역은 〈Fig. 2〉와 같이 평면 단일 암반 균열 의 중심축을 기준으로 한쪽 방향만을 고려하여, 균열을 따라 $0.2 \mathrm{~m}(=\mathrm{Z})$ 그리고 균열과 직각 방향으로 $0.001 \mathrm{~m}(=\mathrm{X})$ 로 정하였다. 본 모델은 혼합 수직 1 차원 모델로, 암반 균열에 서는 $\mathrm{z}$-축 방향으로, 암반 매질에서는 $\mathrm{x}$-축 방향으로 계산 되었고, $\mathrm{y}$-축 방향으로는 $0.052 \mathrm{~m}$ 의 고정된 너비를 가지는 것으로 가정하였다. 모델 실행을 위한 시간적 - 공간적 상수 들은 〈Table 2〉에 정리하였다.

\section{2 모델 검증}

위에서 기술한 핵종/콜로이드 복합이동의 메커니즘을 포함 하는 용질의 이류-분산 방정식의 해석해를 구하는 것은 불가 능하거나 매우 어렵다. 따라서, 본 연구에서는 Tang 등[8]이 보 고한 단일 암반 균열에서 용질의 이동 및 분산에 대한 해석해 와 물질 수지(mass balance) 검사를 통하여 개발된 모델의 검
증을 시도하였다.

\subsection{1 해석해를 통한 모델 검증}

Tang 등[8]의 해석해는 암반 균열에서 이류-분산뿐만 아 니라 Fick의 제1법칙(Fick's first law)을 따르는 암반 매질로 의 확산과 용질의 선형 흡착 평형 등을 포함하고 있다. 이러 한 용질의 흡착을 저해상수(retardation factor; 암반 균열에 서는 $R$, 암반 매질에서는 $R_{M r}$ 로 나타내어 정리된 해석해는 다음과 같다.

$$
\begin{gathered}
\frac{C}{C_{0}}=\frac{\exp (\nu z)}{\pi^{1 / 2}} \int_{l}^{\infty} \exp \left(-\xi^{2}-\frac{\nu^{2} z^{2}}{4 \xi^{2}}\right) \exp \left(-\eta z^{2}\right) \\
\left\{\begin{array}{l}
\left.\exp \left(-\lambda^{1 / 2} Y\right) \operatorname{erfc}\left(\frac{Y}{2 \Gamma}-\lambda^{1 / 2} \Gamma\right)\right) d \xi \\
+\exp \left(\lambda^{1 / 2} Y\right) \operatorname{erfc}\left(\frac{Y}{2 \Gamma}+\lambda^{1 / 2} \Gamma\right)
\end{array}\right)
\end{gathered}
$$

$$
\begin{aligned}
& \text { 여기서, } \quad l=\frac{z}{2}\left(\frac{R}{D_{r} t}\right)^{1 / 2}, \quad \nu=\frac{v}{2 D_{r}}, \quad \eta=\frac{\lambda R}{4 D_{r} \xi^{2}}, \\
& Y=\frac{R z^{2}}{4 D_{r} A \xi^{2}}+B(x-b / 2), \quad \Gamma=\left(t-\frac{R z^{2}}{4 D_{r} \xi^{2}}\right)^{1 / 2},
\end{aligned}
$$

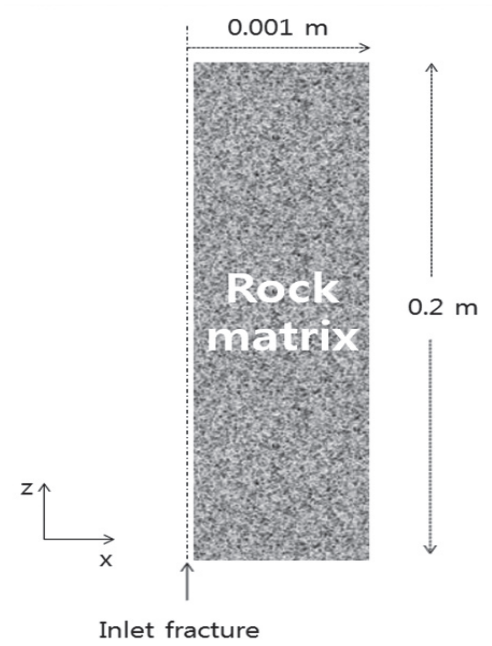

Fig. 2. The domain of virtual model

Table 2. Coefficient values determining temporal and spatial domain of model.

\begin{tabular}{crc}
\hline Parameter & \multicolumn{1}{c}{ Value } & \\
\hline $\mathrm{T}$ & $48 \mathrm{~h}$ & $d t=0.01 \mathrm{~h}$ \\
\hline $\mathrm{Z}$ & $0.2 \mathrm{~m}$ & $d z=0.005 \mathrm{~m}$ \\
\hline $\mathrm{X}$ & $0.001 \mathrm{~m}$ & $d x=0.0001 \mathrm{~m}$ \\
\hline $\mathrm{Y}$ & $0.052 \mathrm{~m}$ & \\
\hline$b$ & $0.0002 \mathrm{~m}$ & \\
\hline$\theta$ & 0.008 & \\
\hline
\end{tabular}


$A=\frac{(b / 2) R}{\theta\left(R_{M r} D_{M r}\right)^{1 / 2}}, B=\left(\frac{R_{M r}}{D_{M r}}\right)^{1 / 2}$ 이고, $C$ 는 암반 균열 및 공극에서의 용질 농도로써 본 모델에서는 $F_{r}$ 와 $P_{r}$ 에 해당하 겠다. 식(32)에서 무한적분 부분은 MATLAB의'Mathematics toolbo®ㅔㅔ 포함된 adaptive Gauss-Kronrod quadrature 함수 를 이용하여 수치 해석적으로 계산되었다.

해석해의 조건을 고려하여, 모델 실행시 콜로이드의 이류분산과 콜로이드의 반응식들은 제외되었고, 오직 용질의 이 류-분산과 암반 매질로의 확산만을 고려하였으며 용질의 흡 착을 고려하지 않아 저해상수 $\left(R\right.$ 과 $\left.R_{M I}\right)$ 는 1로 가정하였다.

아래의〈Fig. 3〉에서 모델 실행 결과와 해석해를 유량을 변화시켜가면서 비교하였다. 모델 검증 단계에서는 계산의 편의를 위해 모델의 시 · 공간적 영역을 결정하는 상수 값들 을 변화시켰는데, 암반 균열 간극의 절반 $(b / 2)$ 을 $0.0005 \mathrm{~m}$ 로, 암반 매질방향으로의 거리 $(X)$ 를 $0.003 \mathrm{~m} \mathrm{(} d X=0.0005$ $\mathrm{m})$ 로 확장하였고, 시간 $(T)$ 은 $24 \mathrm{~h}$ 동안만 확인하였다. 이를 바탕으로 암반 균열에서 유체의 체류시간(retention time)은 유량에 따라서 각각, $q=0.05 \mathrm{~mL} / \mathrm{min}$ 일 때

$$
\frac{0.2(Z) \cdot 0.052(Y) \cdot 0.0005\left(\frac{b}{2}\right)}{0.05 \times 10^{-6}(q)}=104 \mathrm{~min}=1.7 \mathrm{~h}
$$

$q=0.01 \mathrm{~mL} / \mathrm{min}$ 일 때 $8.7 \mathrm{~h}$, 그리고 $q=0.005 \mathrm{~mL} /$ $\min$ 일 때 $17.3 \mathrm{~h}$ 으로 계산된다. 그 결과, 모델 실행 시간 (24h)이 체류시간의 14 배에 달하는 조건인 $q=0.05 \mathrm{~mL} /$ $\min$ 일때는 용질이 균열 전반에 포화되었으며(〈Fig. $3(\mathrm{~A})\rangle)$, 모델 실행 시간이 체류시간의 3 배 이하인 경우 $(q=0.01,0.005 \mathrm{~mL} / \mathrm{min})$ 에는 유출부에서 용질의 파과 (break-through)가 일어나지 못했다(〈Fig. 3(C)〉). $q=$ $0.005 \mathrm{~mL} / \mathrm{min}$ 일 때도 완전한 파과가 일어나지 못했는데, 이는 암반 매질로의 확산이 함께 고려되었기 때문이다. 전 반적으로, 모든 유량 조건에서 암반 균열에서의 용질 농 도분포 결과는 해석해 결과와 비교하여 피어슨 상관계수 의 제곱값 $\left(r^{2}\right)$ 이 0.99 이상으로 모델의 정확성이 입증되 었다. 하지만, 암반 매질 공극에서의 용질 농도분포는 모 델 결과값과 해석해 값이 다소 상이하게 나타났는데, 이는 암반 매질 방향으로의 모델 영역 이산화(discretization) 정도 $(d x)$ 가 암반 균열과 매질의 경계면에서 용질 농도 의 급격한 변화를 나타내기에 부족했기 때문에 나타난 결 로 사료된다.

\subsection{2 물질 수지 (mass balance) 검사를 통한 모델 검증}

본 모델을 검증하는 과정에 있어서 해석해는 몇 가지 가 정을 통한 간단한 조건에서만 본 모델과의 비교가 가능하 므로 추가적인 검증 절차가 필요하다. 따라서 본 논문에서 개발한 모델을 검증하기 위한 추가적인 방법으로 물질 수지 검사를 실행하였다. 물질 수지 검사는 용질의 이동, 용질의 흡착, 용질의 확산, 콜로이드의 이동, 콜로이드의 흡착에 대 한 수식 모델 각각의 결과를 알아보기 위해 다음과 같이 다 섯 가지 조건에서 실행하였다.
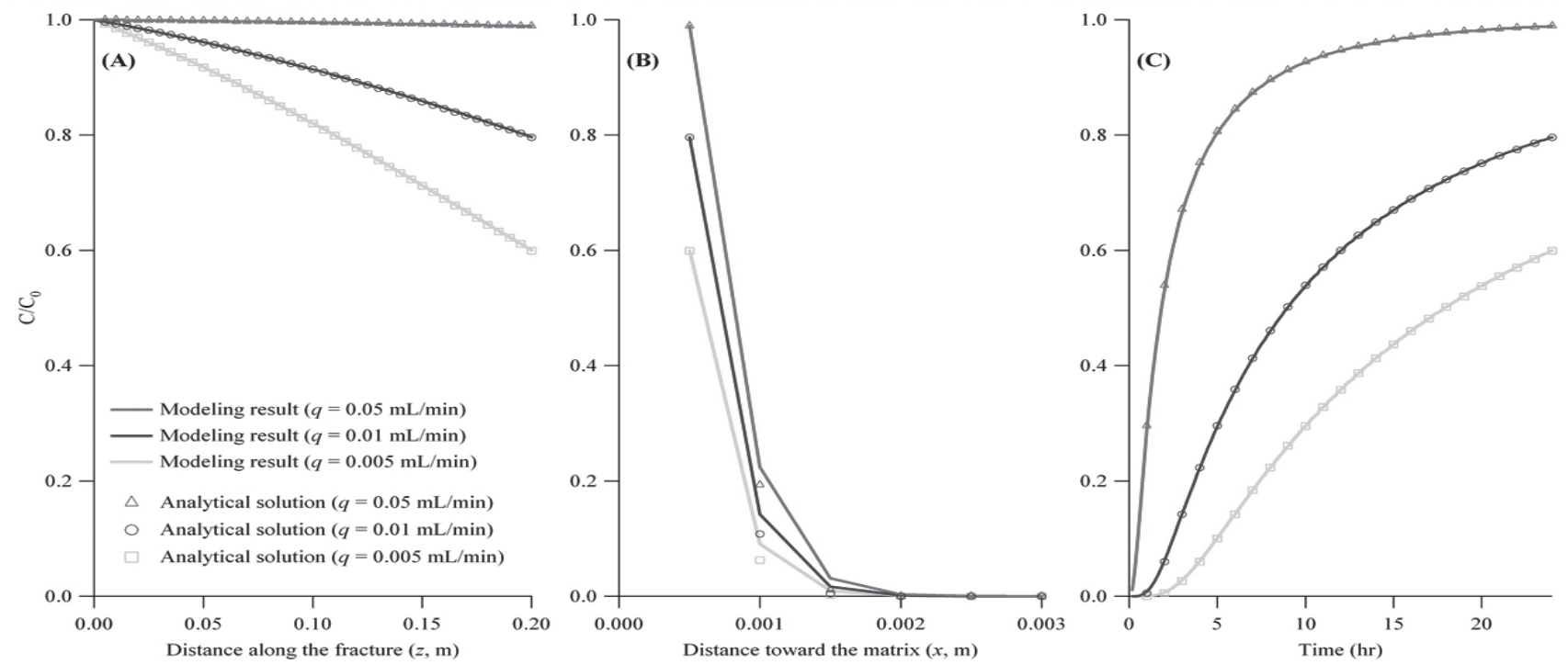

Fig. 3. Model execute results for consequences of different flow rates and comparisons with analytical solution of Tang et al.[8] (A) Spatial distribution of the solute concentration in rock fracture, (B) Spatial distribution of the solute concentration in the direction of outlet of rock fracture toward the matrix rock, $(\mathrm{C})$ Temporal distribution of the solute concentration at outlet of the rock frature. 
Table 3. Mass balance check for the model developed in this study.

\begin{tabular}{lc}
\hline \multicolumn{1}{c}{ Conditions considered } & $\begin{array}{c}\text { Result of mass balance check } \\
(\%)\end{array}$ \\
\hline (1) $[$ Solute transport $]$ & 99 \\
\hline (2) $[(1)+$ Solute Sorption $]$ & 99 \\
\hline (3) $[(2)+$ Solute Matrix $]$ & 100 \\
\hline (4) $[(3)+$ Colloid Transport $]$ & 100 \\
\hline (5) $[(4)+$ Colloid Sorption $]$ & 100 \\
\hline
\end{tabular}

(1) [용질의 이동 방정식]

(2) [(1) + 용질의 흡착과 탈착에 대한 항(term)]

(3) [(2) + 용질의 암반 공극으로의 확산에 대한 항]

(4) [(3) + 콜로이드의 이동 방정식]

(5) [(4) + 콜로이드의 흡착과 탈착에 대한 항(term)]

위 다섯 가지 조건에 대한 물질 수지 검사 결과를 〈Table 3〉에 정리하였고 이를 통하여 본 모델에 대한 정확성을 다 시 입증 하였다.

물질 수지 검사 중 용질의 이동 방정식에 대한 결과와 용 질의 이동 방정식과 용질의 암반 공극으로의 확산에 대한 항을 함께 고려한 결과만 99\%를 나타내는 것을 확인 할 수 있다. 여기에는 두 가지 원인이 예측 되는데 첫 번째 예 측 원인은 컴퓨터 계산으로 인한 절단오차의 발생이다. 두 번째 예측 원인은 해당 모델에서 용질의 질량 유입량에 대 한 식에 분산에 관한 항이 없다는 것이다. 따라서 이 식에 따르면 실제 유입량보다 용질 유입량이 적게 계산되므로 물 질수지 검사에서 다소 오차가 생길 수 있다. 하지만 용질의 유입량에 관하여 분산 효과는 무시 할 수 있을 정도로 작기 때문에 큰 오차는 나타나지 않았고 전반적으로 모든 조건 에서 유입량 대비 회수율이 $100 \%$ 에 근접한 결과를 나타내 어 용질 이동 측면에서 개발된 모델의 정확성 및 안정성을 입증할 수 있었다.

\section{4. 결 론}

본 연구에서는 단일 균열 암반에서 콜로이드가 핵종이동 에 미치는 영향을 규명하기 위하여 수치모델을 새롭게 자 체 개발하였다. 콜로이드의 이동 지배방정식, 핵종 이동 지 배 방정식, 그리고 콜로이드와 핵종의 동역학적 반응들을 동시에 고려하였다. 콜로이드와 핵종의 반응-이동 지배 방 정식을 풀기 위한 수치해석 방법으로는 Operator Splitting Method 중 Strang의 분리 SNI 방식을 채택하여 컴퓨터 계 산 효율 증대를 도모하였고 이는 MATLAB을 이용하여 코
드화 되었다.

이렇게 개발된 수치모델은 용질(핵종)의 이동 및 분산만 을 고려한 해석해를 통한 검증과정에서 피어슨 상관계수 의 제곱값 $\left(r^{2}\right)$ 이 0.99 이상으로 나타나 모델의 정확성이 입 증되었다. 또한 본 모델의 추가 검증을 위한 물질 수지 검사 를 실행하여 모델의 정확성을 한번 더 입증하였다. 본 연구 는 실험실 칼럼 실험을 염두에 둔 가상 조건에서의 모델 실 행 결과로써 향후 본 연구에서 개발된 수치모델과 실험을 비 교함으로써 수치모델의 정확성 및 안정성을 한층 더 확실히 입증할 수 있을 것으로 보인다.

\section{REFERENCES}

[1] Min-Hoon Baik and Won-Jin Cho, "An Experimental Study on the Sorption of Uranium(VI) onto a Bentonite Colloid", J. of the Korean Radioactive Waste Society, 4(3), pp.235-243(2006).

[2] Andre R., Dirk-Alexander B., Richard S., "The Importance of Bentonite Colloids on the Radionuclide Transport in the Far-Field of a Waste Repository in Granite", Gesellschaft fur anlagen und Reaktorsicherheit (GRS) mbH Braunschweig, Germany.

[3] R.W. Buddemeier, J.R. Hunt, Transport of colloidal contaminants in groundwater : radionuclide migration at the Nevada Test Site, Appl. Geochem. 3 , pp.535-548 (1998).

[4] Min-Hoon Baik, Jae-Kwang Lee and Jong-Won Choi, "Research Status on the Radionuclide and Colloid Migration in Underground Research Facilities", J. of the Korean Radioactive Waste Society, 7(4), pp.243253 (2009).

[5] S.H. Li, H. Yang, C.P. Jen, Modeling of colloid transport mechanisms facilitating migration of radionuclides in fractured media, Nucl. Technol. 148, pp.111(2004).

[6] Bear, J., Dynamic of Fluids in Porous Media, Elsevier, New York (1972).

[7] Carrayrou, J.; Mose, R.; Behra, P., "Operator-splitting procedures for reactive transport and comparison of mass balance errors", Journal of Contaminant $\mathrm{Hy}$ drology, 68, pp.239-268 (2004).

[8] Tang, D.H.; Frind, E.O.; Sudicky, E.A., Contaminant transport in fractured porous media; Analytical solu- 
Sanghwa Lee. et al : Development of the Numerical Model for Complex Transport of Radionuclide and Colloid in the Single Fractured Rock

tion for a single fracture. Water Resources Research , 17(3), pp.555-564 (1981).

[9] Jung-Woo Kim and Min-Hoon Baik, "Development of the Numerical Model for Reactive Transport of Radionuclide and Bacteria in the Single Fractured Rock", Korea Atomic Energy Research Institute, KAERI/TR-4196/2010 (2010).

[10] Jung-Woo Kim, Min-Hoon Baik, Seung-Yeop Lee and Jong-Min Oh, "The Effects of Bacteria on the Radionuclide Migration in the Fractured Rock", Korea Atomic Energy Research Institute, KAERI/TR4442/2011 (2011). 